\title{
Policy Formulation of The Marine Governance in The Coastal Southern Lebak Regency Banten Province
}

\author{
Delly Maulana ${ }^{1}$ and Arif Nugroho ${ }^{1}$
}

${ }^{1}$ Department of Public Administration, Faculty of Social, Political, and Law Sciences, Universitas Serang Raya, Jalan Serang-Cilegon KM 5 (Taman Drangong) Serang-Banten, Indonesia; e-mail: delly maulana@yahoo.com

\begin{abstract}
ABSTRAK
Tulisan ini bertujuan untuk menjelaskan keberadaan potensi kelauatan di kawasan pesisir selatan Kabupaten Lebak Provinsi Banten yang belum dimanfaatkan secara maksimal. Terdapat beberapa potensi kelauatan di Kabupaten ini, yakni luas garis pantai sekitar $91,42 \mathrm{~km}^{2}$, serta sumberdaya kelautan dan perikanan yang dapat dikembangkan. Potensi tersebut tidak hanya di sektor perikanan dan pariwisata, tetapi juga pertambangan. Dengan laju pembangunan yang tinggi di wilayah pesisir Kabupaten Lebak tentunya akan menimbulkan berbagai permasalahan di wilayah tersebut, seperti Pertama, degradasi ekosistem pesisir dan laut di Kabupaten Lebak; Kedua, meningkatnya intensitas pencemaran lingkungan akibat kegiatan pertambangan; Ketiga, kerentanan terhadap bencana alam (abrasi, tsunami, erosi, perubahan iklim, dan lain-lain); Keempat, terjadinya konflik pemanfaatan ruang; dan Kelima, rendahnya produktivitas pemanfaatan sumber daya hayati laut. Metode yang digunakan dalam penelitian ini adalah metode penelitian kualitatif dengan wawancara mendalam, observasi, dan dokumentasi. Hasil penelitian menunjukkan ada dua permasalahan yang menjadi permasalahan pengelolaan kelautan di wilayah pesisir selatan Kabupaten Lebak, Pertama adalah kerusakan lingkungan, yang Kedua adalah konflik penggunaan ruang, dan yang Ketiga adalah pencemaran sampah akibat sampah organik dan non-organik. Sedangkan dalam pemetaan aktor menunjukkan bahwa pemerintah, dalam hal ini Bupati sebagai otoritas di daerah yang memiliki kekuasaan, pengaruh, dan kepentingan untuk memberikan masukan bagi pengelolaan laut di Pantai Selatan Kabupaten Lebak agar tidak hanya meningkatkan Pendapatan Asli Daerah (PAD) tetapi juga berpengaruh secara signifikan terhadap masyarakat lokal, terutama nelayan dan kelestarian lingkungan.
\end{abstract}

Kata kunci: Formulasi kebijakan, Governance, Ekonomi kelautan, Keberlanjutan, Kesejahteraan masyarakat

\begin{abstract}
This paper is aimed to explain the presence of marine potentials in the southern coastal area of Lebak Regency, Banten Province that have not been fully exploited. There are several potentials found in this Regency, the extensive coastline of approximately $91.42 \mathrm{~km}^{2}$, and the marine resources and fisheries that could be developed. The potentials include not only fisheries and tourism but also mining. With such a high rate of development in the coastal area of Lebak Regency, it will certainly cause various problems in the region such as First, the degradation of coastal and marine ecosystems in Lebak Regency; Second, the increasing intensity of environmental pollution caused by mining and extraction activities; Third, the vulnerability to natural disasters (abrasion, tsunami, erosion, climate change, et cetera); Fourth, the occurrence of area utilization conflict; and Fifth, low productivity of biological marine resources utilization. The method used in this study was a qualitative research method with in-depth interviews, observations, and documentation. The results show that two issues become marine management problems in the southern coastal area of Lebak Regency, the first is environmental degradation, the second is space use conflicts, and the third is waste pollution due to organic and non-organic waste. Meanwhile, actor mapping shows that the government, in this case, the Regent as the authority in the area, has the power, influence, and inter est to give input to the marine management of the Southern Coast of Lebak Regency so that it would not only increase the local revenue but also have a significant effect on the local communities, especially the fisher people and, and the environmental sustainability.
\end{abstract}

Keywords: Policy formulation, Governance, Marine economy, Sustainability, Public welfare

Citation: Maulana, D., dan Nugroho, A. (2020). Policy Formulation of The Marine Governance In The Coastal Southern Lebak Regency Banten Province. Jurnal Ilmu Lingkungan, 18(3), 565-571, doi:10.14710/jil.18.3.565-571

\section{Introduction}

As the largest archipelagic country in the world, Indonesia is also known as a maritime state with waters reaching 5,8 million $\mathrm{km}^{2}$ which consists of 3.1 million $\mathrm{km}^{2}$ of territorial waters and 2,7 million $\mathrm{km}^{2}$ of Indonesia's Exclusive Economic Zone (EEZ). Indonesia's coastal area and small islands consist of 17,504 islands and a coastline of $95,181 \mathrm{~km}^{2}$. This condition is both a blessing and an economic potential that could be utilized for the advancement and welfare 
of the nation. (Aknar, 2014) Conceptually, Indonesia's maritime development consists of seven sectors: sea transportation, fisheries, marine tourism, maritime industries, energy and mineral resources, maritime infrastructure, and marine services (Kusumawardhani \& Afriansyah, 2019).

Banten Province's coastal area, especially that in Lebak Regency, has been relatively unexploited to its maximum potential if compared to the southern coast which is under Pandeglang Regency's jurisdiction even though it has potential in its natural resources, including its marine economy. The coastal area has a coastline of approximately $91.42 \mathrm{~km}$ and has marine and fishery resources that can potentially be developed such as the catch fishery industry, the aquaculture industry, the fish-processing industry, the marine biotechnology industry, the sea-salt industry, and non-conventional natural resources.

In addition to the fishery potential, the coastal area's tourism potential could also be developed. At the moment, there are many tourism attractions found on the southern coast of Banten, especially those located in Lebak Regency, namely: Sawarna Beach (Bayah Sub-District), Ciantir Beach (Bayah SubDistrict), Karang Tengah Beach (Wanasalam SubDistrict), Tanjung Panto Beach (Wanasalam SubDistrict), Karang Taraje Beach (Bayah Sub-District), et cetera. Another potential that could be developed in the southern coast of Banten is the mining and extraction potential. This potential is found in some sub-districts, Wanasalam Sub-District, Panggarangan Sub-District, Bayah Sub-District, and Cilograng SubDistrict. The Lebak Sub-District Integrated Licensing Service Agency (Badan Pelayanan Perizinan Terpadu (BPPT) has even revealed that investments for the mining and extraction resource-based industry in this area has reached IDR 7.6 trillion since the Merah Putih Cement Mill started operating. The Merah Putih Cement Mill belongs to PT Cemindo Gemilang which is located in Bayah Sub-District (Lebak dalam Angka Tahun 2019, 2019).

The high-velocity development in the southern coast of Banten would of course cause problems such as: First, the degradation of the coastal and marine ecosystem; Second, the intensity of pollution due to mining and extraction activities; Third, the threat of natural disasters (abrasion, tsunami, erosion, climate change, et cetera); Fourth, space utilization conflicts; and Fifth, the low productivity of living marine resource utilization.

These conditions require a formulation of policies for good and sustainable marine governance on the southern coast of Banten Province, one of which is by developing managing institutions in the area. The involvement of stakeholders through collaborative and comprehensive planning is an absolute must for creating a sustainable coast and marine area by emphasizing the understanding that the local people still rely heavily on the coastal area. This is stated in Law number 1 Year 2014 as a replacement for Law number 27 Year 2007 about the Management of Coastal Areas and Small Islands (PWP-3-K)(RI, 2014). 566
In this law, it is stated that the management of coastal and marine areas is a chain of planning, utilization, controlling, and monitoring activities of the coastal and small island resources.

The mapping related to marine management studies showed that the purposes, aims, and targets of marine management should prioritize sustainability based on the ecosystem approach, must be technologically, politically and socially appropriate, ethical and must support the purposes of Sustainable Development Goals (SDGs). (Cormier \& Elliott, 2017). This concept is supported by Rachel, Charles, and Stephenson who provided a description where maritime management must be ecosystem-based with consideration of adaptive management, emphasizing the involvement of the stakeholders in the management. (Long, Charles, \& Stephenson, 2015). Furthermore, to prioritize sustainable maritime management policies, there needs to be a reformation of the budgeting management to support them and to involve all the interest groups. (Mohammed, Steinbach, \& Steele, 2018). This was also the image painted by another study which stated that conservation-based maritime management must be supported by the public perception that the policies will have a positive impact on the people's social, economic, and cultural conditions. (James \& Dearden, 2014)

Therefore, to realize the good coastal and small islands governance in the southern coast of Banten Province, this study will formulate marine governance policies in the southern coastal area of Banten Province, especially the area in Lebak Regency, both in the form of marine problem and potential identification and in the formulation of governance policies for the southern coast of Lebak Regency so that it would have an effect on increasing the ownsource revenue (PAD), and at the same time have an effect on the local people's welfare by focusing on the sustainable marine governance perspective.

\section{Research Method}

This study employed a qualitative method. According to Creswell, data collection in a qualitative study is conducted through observations, interviews, document reviews, and audiovisual materials. In this study, the data collection was conducted through observations, interviews, and literature review (Creswell, 2009). The study locus was the Lebak Regency southern coast through the observation of marine potentials and issues that might become a problem in the Lebak Regency southern coast. Also, several informants were interviewed such as the Lebak Regency Fisheries and Marine Affairs Agency, Lebak Regency Agency for Regional Development (Bappeda), fishers, Lebak Regency Environmental Service, and two extraction actors. Secondary data were taken from a few study report documents, articles, and regulations related to the present study. Analysis data was done using the Nvivo 12 Pro qualitative software. 


\section{Result and Discussion}

\subsection{Marine Issues in the Southern Coast of Lebak} Regency

Policy formulation is a stage in the policy cycle (Amanta \& Kusumasari, 2019; Bertscher, London, \& Orgill, 2018). Studies about policy formulation concentrate on the characteristics of public issues (formulation).

The study identified several issues regarding the management of marine potentials on the southern coast of Lebak Regency: First, the issue of coastal and marine ecosystem degradation. The condition of the coast before the presence of sand extractions along the coast boasted beautiful and natural beaches with various vegetation growing along the coastline. However, this has been replaced by sand extractions operations, and the color of the seawater has become more turbid due to the sediments churned up by the extractions. This is due to the booming of sand extraction along the coast of Cihara Sub-District or in the Cibobos forest. The extraction activities have been going on for some time, causing terrible abrasions to the beach. Hundreds of cubic meters of sand are extracted and transported by truck from the beachfront near Cihara Bridge to be delivered to buyers. The sand extractors on Cihara Beach and other beaches along Southern Lebak usually use the traditional method. If the sand extracting business is allowed to continue, it will bring grave effects on the surrounding environment. Much of the beachfront has been damaged due to abrasions, and in some areas, it has even breached the roadsides. (Figure 1).
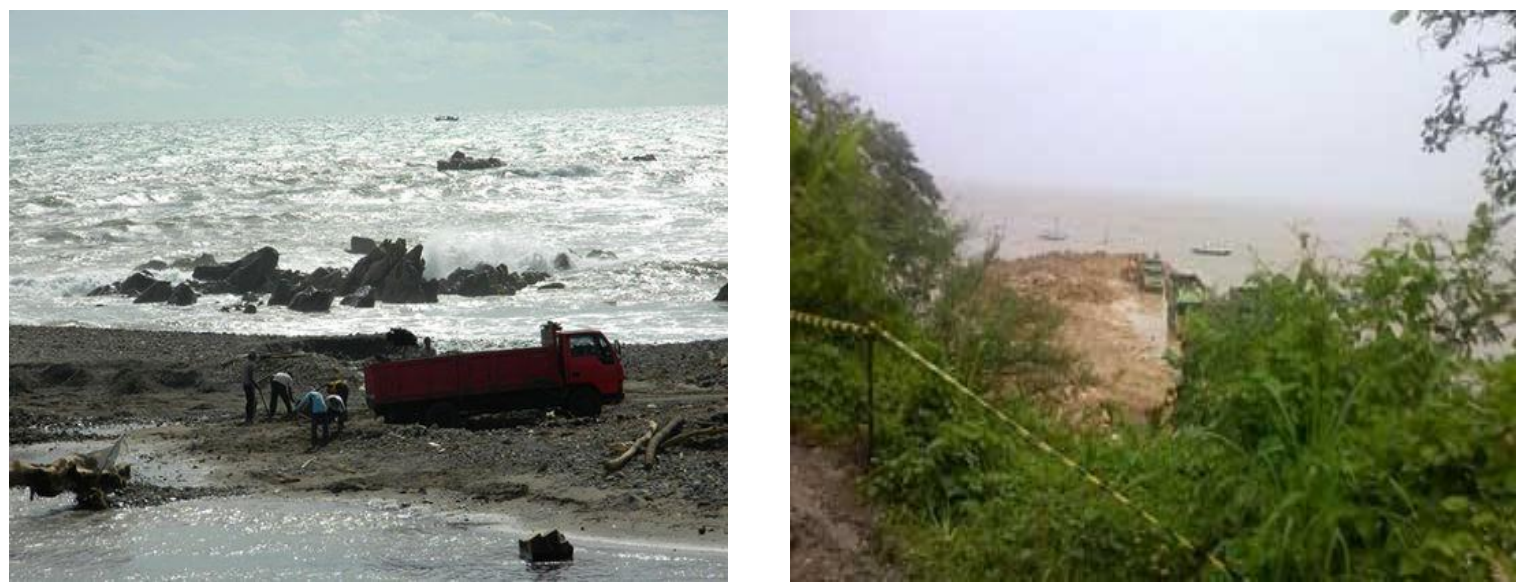

Figure 1 Sea Sand Extraction Process

The second is the spatial utilization conflicts on the southern coast of Lebak Regency. The fishers in Bayah Sub-District have complained about the loss of mooring for their boats after PT Gama reclaimed Darmasari Beach for the construction of a company dock for this cement producer. From the beginning of the construction of the dock, the fishers were never consulted or given an explanation. The company also refused to relocate the fishers. The beach to become PT. Gama Group's major dock extends over an area exceeding 600 meters, from Karangtaraje tourist's beach to Jogjogan in Darmasari Village, Bayah Subdistrict. Previously, the location was a mooring area for hundreds of fishing boats belonging to the fishers of Bayah. About 300 fishers regularly moored their fishing vessels there. Since the beginning of the project, the fishers were naturally dislocated with no compensation whatsoever from the company.

Third, the results of the observation and interview with the Lebak Regency Fisheries and Marine Affairs Agency showed that there was a bit of water pollution in the southern coast of Lebak Regency caused by household waste from residential areas and waste from the cement factory in the form of organic and inorganic materials. The main sources of pollution are agricultural activities and residential areas. The pollutants enter the waters through the rivers. Household waste and agricultural fertilizers that flow from the river headwaters that enter the coastal area will increase plankton biomass in the waters and the sea. An excessive increase in plankton biomass could have negative impacts such as causing a lack of oxygen, poisoning the marine biota, and disrupting the esthetic value of the waters. Pollutants from agricultural and household activities usually consist of nitrogen, phosphates, and potassium. (Barokah, Kurniasari, \& Gunawan, 2016; Herlianti \& Prijadi Soedarsono, 2016; Pratama, 2018) Besides, disruption of the environmental balance will influence the esthetic value of the area which in turn will affect the development of the tourism sector.

\subsection{Actors Involved in the Formulation of Marine Management Policies in the Southern Coast of Lebak Regency}

In identifying the actors involved in the process of formulating the marine management policies on the southern coast of Lebak Regency, there needs to be an analysis of the stakeholders. According to Ondee and Pannarunothai, stakeholder analysis is a systematic method to collect and analyze data of the actors' (individuals, groups, or organizations) interests in order to identify the policy actors, especially the lead actors in a policy system, assess their interests (wagering), and predicting the potential influences on the development and implementation of the policies. 
There are 6 (six) processes involved in the analysis of stakeholders: First, identifying the main purpose of the stakeholder analysis, identifying the policies and developing an understanding of the system and the decision-makers within that system; Second, identifying the main stakeholders; Third, collecting and recording the stakeholder analysis data; Fourth, identifying the patterns and interaction contexts between the stakeholders; Fifth, investigating three key-stakeholder characteristics which consist of power, interests, and influence and classifying the stakeholders; Sixth, defining the alternative policies and utilizing the information from the stakeholder analysis.

In a study about the policy formulation, it is important to view how the actors influence the policy formulation. (Bertscher et al., 2018) While Barca (Anderson, 2003; Politecnico, 2017; Riet, 2003; Rijal, Madani, \& Fatmawati, 2013) stated when identifying the actors, there are several types of actors based on the way they influence policy decisions: political actors, bureaucratic actors, actors with special interests, actors with general interests, and experts. Political actors are those who represent elected actors who have access due to a ruling, whereas bureaucratic actors are actors in the administrative sector and these people influence the decision-making process based on their responsibilities. Actors with special interests are actors, that include individuals and organizations, whose involvement in the decisionmaking process have the ability to intervene in the subject in the decision-making process. Actors with a general interest are those who base their claims on their ability to intervene with the ruling process. Experts are those who, based on their claim, have a right to intervene based on the facts they have because they possess the required knowledge, necessitating as much of their involvement as possible in the decision-making process.

The process of mapping all the actors involved in the marine management formulation process in the southern coastal area of Lebak Regency showed that the actors were the Regent, the Agency for Regional Development (Bappeda), the Marine and Fisheries Service, the Environmental Agency (Badan Lingkungan Hidup), the Navy/police, large companies (cement factory), NGOs that work on environmental issues, mass media, the Government Tourism Office, fisher communities, individual extractors, and communities working in tourism businesses.

Table 1. The Power, Interest, and Influence of the Actors in the Marine Management of the Southern Coast of Lebak Regency

\begin{tabular}{clccc}
\hline No & \multicolumn{1}{c}{ Actors } & Power & Influence & Interests \\
\hline $\mathbf{1 .}$ & Regent & High & High & High \\
$\mathbf{2 .}$ & Agency for Regional Development & High & High & High \\
$\mathbf{3 .}$ & Marine and Fisheries Service & High & High & High \\
$\mathbf{4 .}$ & Environmental Agency & High & High & High \\
$\mathbf{5 .}$ & Navy/police & High & High & High \\
6. & Large companies & High & High & High \\
$\mathbf{7 .}$ & NGOs & Medium & High & High \\
$\mathbf{8 .}$ & Mass media & Medium & High & High \\
$\mathbf{9 .}$ & Government Tourism Office & Medium & Medium & High \\
$\mathbf{1 0 .}$ & Fisher communities & Low & Low & High \\
$\mathbf{1 1}$ & Extractors & Medium & High & High \\
$\mathbf{1 2}$ & Tourism communities & Medium & High & High \\
\hline
\end{tabular}

The results of the actor mapping based on their power, influence, and interests through in-depth interviews of several informants and by viewing the actors' respective authorities showed that the government, in this case, the Regent as the person with the highest authority in the regency, had the power, influence, and interest to give suggestions for the marine management in the southern coast of Lebak, Banten so that it would not only increase the regional revenue but also have a significant effect on the local communities, especially the fisher people, and on the environmental sustainability. The fisher people have weak power and influence but are have a lot of interest in the quality of the marine environment (Table 1). The fisher people are even highly dependent on the sustainability of marine resources. Dahuri stated that fishers are people who catch fish (or cultivate) in the sea and areas affected by the tides.

\subsection{Formulation of the Marine Potential Governance Policies in the Coast of Lebak Regency}

Fishers also have unique characteristics not found in other communities, which is they are harsh and face many risks, and are strongly dependant on natural factors, especially in inclement and fickle weather which can be very disruptive to their activities. (Liliek Soeprijadi Soeprijadi, Yuli, Susilo, \& Rudianto, 2013; Sadat, Basir, \& Nazar, 2018; Yeninda \& Elni Sumiarti, 2016)

Therefore, there needs to be support from all the government elements (the Agency for Regional Development (Bappeda), the Marine and Fisheries Service, the Environmental Agency (Badan Lingkungan Hidup), the Navy/police). In addition, the private sector and communities (Environmental NGOs, fisher communities, and extraction actors) could exert control over themselves in overzealously conducting economic activities without any thought of sustainability.

The issues that have entered the policy agenda are discussed by the policymakers. The aforementioned issues were defined to then have their solutions found. In this phase, forecasting is needed. According to 
Dunn, forecasting can provide knowledge relevant to the policies regarding issues in the future as an effect of taking alternatives, including the choice of doing nothing. In addition, according to Dunn also, policy forecasting has three main forms: projection, prediction, and forecast. Projections are forecasts based on the extrapolation of past or current trends to the future. Projections could be strengthened by arguments from authorities (such as expert opinions) and casual logic (economic and political theories). On the other hand, predictions are forecasts based on strong theoretic assumptions. On the other hand, forecasts are based on informative assessments or expert evaluation on the situation of people in the future (Dunn, 2014; Mara S. Sidney, 2007; Oliver, 1986; Weimer \& Vining, 2017; Wildavsky \& Jasanoff, 2006).

According to Serban, there are several phases in the policy formulation process: (1) identifying the aims of the new policy - focusing on some main strategic aims in detail; (2) determining the criteria (oriented on impact) of the policy alternatives; (3) selecting the policy alternatives of choices; (4) evaluating the ex-ante effect of one of the alternative policies that was selected; and (5) describing the policy choice and connecting it to the policy effects or results. Therefore, in this phase, policy analysis requires the collection and analysis of information related to the issue, development of policy alternatives, building support, and negotiating until a policy is selected (Anderson, 2003; Madlen Serban, 2015; Maulana, Larasati, \& Suwitri, 2019).

Sustainable development is closely related to the economy and the environment. Development is usually related to the economy, while the environment is related to ecology. Economic development usually has goals to increase the "production" of goods and services for the betterment of welfare-ecological preservation to produce environmental services (Herman Haeruman, 1997). Sustainable development requires several conditions: (1) only sustainable products are exploited from resources that are renewable and the long-term production ability is maintained; (2) the profit or results obtained from unrenewable resources are invested into human resources, artificial resources, and technology; (3) the environment's ability to accept and absorb waste is not exceeded or damaged; and (4) the management system is effective and efficient.

Meanwhile, if the sustainable development concept is connected to the marine potential improvement concept, the concept aligns because development which is balanced between the economic aspect and the environmental aspect is a development principle which is always the basic foundation for all the sectors and regions to ensure the sustainability of the development itself.

The abundant marine potentials on the southern coast of Lebak Regency, Banten Province must be managed sustainably to have a significant effect on the local people's welfare. Therefore, there needs to be well-aimed policies that consider several aspects, namely that the marine management must be based on the ecosystem with considerations of adaptive management, involve the stakeholders (the government, the public, and businesspeople) in the management so that it may be conducted holistically and integrally, put forth appropriate technology so it does not damage the ecosystem or the fisherpeople's livelihood, and consider the socio-cultural aspects of the local people. This can be seen in the diagram below:

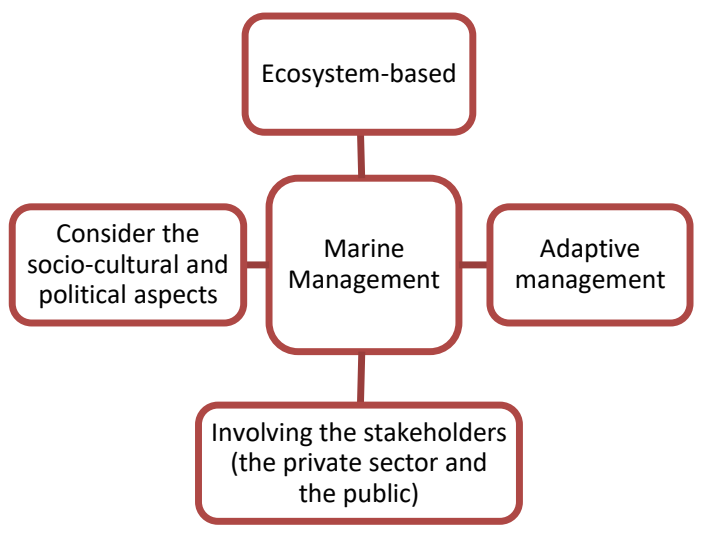

Figure 2. Marine Management in the Southern Coast of Lebak

The results of the interviews, observation, and study report documents related to the southern coast of Lebak Regency suggest that there are a few policy formulations to improve the marine management in the southern coast of Lebak Regency. First, Controlling and utilizing the superior and globally competitive marine resource products. This alternative aims to control and utilize the marine resource products efficiently or not excessively and by using the proper methods that do not antagonize the marine ecosystems in the coastal area, especially products that are globally competitive such as lobsters, superior fisheries, and non-fish biological products such as seaweed, seas cucumbers, et cetera. If implemented, this formula could cause improvements to the marine productivity on the southern coast of Lebak, leading to a growth in the regency's local revenue and at the same time improving the people's welfare. At present, the fishery products are the only livelihood in this coastal area, non-fishery products that are considered to have superior market potential have not been developed fully. Therefore, increasing the control and utilization of superior and globally competitive marine resources is one of the alternatives to improve the marine economic potential along the southern coast of Lebak Regency.

Second, Formulation of sustainable spatial planning and coastal area ecosystem quality. Spatial conflicts due to mining and extraction activities are an issue on the southern coast of Lebak Regency. This activity has been going on for a long time and has caused serious abrasion to the beach. Therefore, 
sustainable spatial planning policies and coastal area ecosystem quality is one solution to this problem and it could at the same time improve the marine economic potential on the southern coast of Lebak Regency. Several activities could be done to implement these policies: zoning activities on the southern coast of Lebak Regency, increasing the number of marine conservation areas, devising a strategic plan for the coastal area through the involvement of other stakeholders in creating a sustainable coastal area.

Third, Formulation of the fairly large marine fishery resource potential in Lebak Regency. Lebak Regency has a coastline of approximately $91.42 \mathrm{~km}$ with a sustainable potential for coastal waters and Exclusive Economic Zone (EEZ) of 10,557.24 tons/year which consists of $3,712.40$ tons/year coastal waters sustainable potential and 6.844,84 ton/year EEZ potential (B. Lebak, 2017). With these potentials, the development policies for aquacultural technology, fishing technology, and fishery product processing technology are one of the alternatives for improving the marine economic potential on the southern coast of Lebak Regency. Some measures could be taken with these policies, for example, technology-based fishery management, modern fish capture, and the development of technology-based aquaculture so that the productivity of the fishery sector could increase and have an impact on the increase fisher welfare in the area.

And Fourth, Formulation of policies to improve and develop tourism potentials. These policies are based on the fact that Lebak Regency is dominated by coastal tourism potentials, especially on the southern coast of Lebak Regency. Many sub-districts have tourist attractions such as Malingping Sub-District, Panggarangan Sub-District, and Bayah Sub-District. Besides, most tourists, both domestic and international, visit coastal tourist attractions. Therefore, this potential is a potential that could be developed to improve the marine economic potential on the southern coast of Lebak Regency. Many activities could be conducted in the implementation of this policy: improvements in road infrastructure and tourist attraction facilities. Besides, the community empowerment activities to improve the tourism sector is an important detail in maximizing this potential.

\section{Conclusion}

There are some conclusions that could be made from this study: First, the fishery and marine resource potentials in the southern coast of Lebak Regency (coast and beach) are quite large but have not been utilized optimally; Second, there are a few non-fish biological (coral reef, seaweed, lobsters, and edible bird's nests) and nonbiological (metal and nonmetal minerals) resource potentials in almost all the subdistricts along the southern coast of Lebak Regency; and the Third is the mineral extraction activities conducted along the southern coast of Lebak Regency is causing environmental and social problems.
Therefore, to solve these issues, there needs to be a few policy priorities: First, to reduce environmental degradation, spatial conflicts, and pollution by formulating strict permit regulations by prioritizing spatial policies and sustainable coastal ecosystem quality; Second, to create environmentally-friendly fishery and non-fishery sectors through various programs for improving the fisher community's economic welfare; and Third, to improve the tourism sector with considerations of the environmental ecosystem aspects.

\section{REFERENCES}

Aknar, I. 2014. Potensi Investasi Kelautan Indonesia. Balai Besar Penelitian Sosial Ekonomi Kelautan Perikanan. Hal 5-6.

Amanta, L., \& Kusumasari, B. 2019. Intervensi Aktor dalam Mempengaruhi Formulasi Kebijakan Lingkungan: Studi Kasus Kebijakan Relokasi Tambak Udang di Yogyakarta. Jurnal Borneo Administrator, Vol. 15 No. 2. Hal 179-198.

Anderson, J. E. 2003. Public Policymaking. Boston New York. Houghton Miffin Company.

Barokah, G. R., Kurniasari, A., dan Gunawan. 2016. Kelimpahan Fitoplankton Penyebab Hab (Harmful Algal Bloom) di Perairan Teluk Lampung Pada Musim Barat Dan Timur. JPB Kelautan dan Perikanan, Vol. 11 No. 2. Hal 115-125.

Bertscher, A., London, L., and Orgill, M. 2018. Unpacking Policy Formulation and Industry Influence : The Case of The Draft Control of Marketing of Alcoholic Beverages Bill in South Africa. Pages 786-800.

Cormier, R., and Elliott, M. 2017. Smart Marine Goals , Targets and Management - Is SDG 14 Operational or Aspirational, is 'Life Below Water' Sinking or Swimming ? Marine Pollution Bulletin, Vol. 123 No. 12. Pages 28-33.

Creswell, J. 2009. Research Design. Journal of Chemical Information and Modeling, Vol. 53 No. 9. Pages 16891699.

Herlianti, J., dan Prijadi Soedarsono. 2016. Hubungan Antara Kandungan Nitrat, Fosfat dan Klorofil-A di Sungai Kaligarang, Semarang. Diponegoro. Journal of Marqueares, Vol. 5 No. 1. Hal 69-74.

James, N., and Dearden, P. 2014. Why Local People do not Support Conservation: Community perceptions of Marine Protected Area Livelihood Impacts , Governance and Management in Thailand. Marine Policy, Vol. 44. Pages 107-116.

Kusumawardhani, I., dan Afriansyah, A. 2019. Kebijakan Kelautan Indonesia dan Diplomasi Maritim. Kertha Patrika, Vol. 41 No. 3.

Lebak, B. 2017. Kabupaten Lebak dalam Angka 2017. Kabupaten Lebak. CV. Karya Amanah Art.

Liliek Soeprijadi Soeprijadi, Yuli, E., Susilo, E., and Rudianto, R. 2013. Fishermen Community Economic Empowerment Through Joint Development Business Group in Cirebon City. The International Journal of Marine Science, Vol. 3. Pages 1-9.

Long, R. D., Charles, A., and Stephenson, R. L. 2015. Key Principles of Marine Ecosystem-Based Management. Marine Policy, Vol. 5. Pages 53-60.

Mohammed, E. Y., Steinbach, D., and Steele, P. 2018. Fiscal Reforms for Sustainable Marine $\mathrm{Fi}$ Sheries Governance: Delivering The SDGs and Ensuring no 
one is Left Behind. Marine Policy, Vol. 93. Pages 262270.

Politecnico, T. 2017. Mapping The Transformation for The Competitiveness of A and Prof . Marzia Morena Actors and Roles In Decision-Making Process.

Pratama, S. W. 2018. Indeks Pencemaran Air Laut Pantai Selatan Bantul dengan Parameter TSS dan Kimia NonLogam. Universitas Islam Indonesia.

RI. 2014. Undang-Undang Nomor 1 Tahun 2014 tentang Perubahan Atas Undang-Undang Nomor 27 Tahun 2007 tentang Pengelolaan Wilayah Pesisir dan PulauPulau Kecil.

Riet, O. van de. 2003. Policy Analysis in Multi-Actor Policy Settings. Netherlands. Eburon Publisher.
Rijal, F., Madani, N., dan Fatmawati. 2013. Interaksi Aktor dalam Perumusan Kebijakan Pengelolaan Pertambangan di Kabupaten Kolaka Utara. Otoritas, Vol. III No. 2. Hal 14-26.

Sadat, A., Basir, M. A., dan Nazar, A. 2018. Pemberdayaan Masyarakat Nelayan dalam Penglolaan Sumber Daya Alam Laut Terhadap Peningkatan Ekonomi yang Berkelanjutan di Desa Kakenauwe dan Desa Wagari Kecamatan Lasalimu. Jurnal Pengabdian Kepada Masyarakat Membangun Negeri, Vol. 2 No. 1. Hal 1-19.

Yeninda, \& Elni Sumiarti. 2016. Dampak Program Pemberdayaan Ekonomi Masyarakat Nelayan Terhadap Peningkatan Pendapatan di Kabupaten Pasaman Barat. Menara Ilmu, Vol. X No. 72. Hal 133140. 